\title{
Memory Transmission in The Secret Life Of Bees Novel: A Study Of Postmemory
}

\author{
Titin Astina ${ }^{1}$, Haris Kurniawati ${ }^{2}$ and Lia Haryana ${ }^{1}$ \\ ${ }^{1}$ Universitas Gadjah Mada, Indonesia \\ ${ }^{2}$ Universitas Gadjah Mada, Indonesia \\ ${ }^{3}$ Department of English Language Teaching (ELT), Universitas Negeri Malang (UM), Indonesia
}

\begin{abstract}
Racism in the United States has led to many movements aimed at banning racial discrimination against African-Americans and restoring their voting rights in the United States, which we know as the African-American Civil Rights Movement. However, it gave rise to trauma that led to the hopes held by the black nation. With the passage of the Civil Code black citizens hope to regain their rights and freedoms that have been deprived of arbitrarily by white citizens. But on the other hand it also indirectly bequeathed trauma to their next-generation both for the black nation and for the white nation. The Secret Life of Bees by Sue Monk Kidd illustrates the tension and inequality that existed in South America in the 1960s. How racism is transmitted is reconstructed while describing the suffering experienced by black people due to racism.

This study aims to reveal the memory transmission that exists in the novel The Secret Life of Bees from Sue Monk Kidd. This research also aims to uncover the memory reconstruction in the novel The Secret Life of Bees. The results of this study are the discovery of relations from the process of memory transmission and memory reconstruction who lead to how black people see white skin and vice versa. Also, it was also found that it was not a traumatic event experienced by survivors and passed on to the next generation who became traumatic but the impact caused by the traumatic event itself.
\end{abstract}

Keywords: Transmission, Reconstruction, Postmemory, Racism, African-American Civil Rights Movement, Traumatic, Sue Monk Kidd, The Secret Life Of Bees

\section{Introduction}

Racism in the United States has been rife since the colonial era. Legally and socially, white Americans can obtain their rights as citizens but not Native Americans, African Americans, and Hispanics or Latino Americans. European Americans (especially white Anglo-Saxon Protestants) have exclusive rights in educational materials, immigration, voting rights, citizenship, land ownership, and criminal procedures over a period stretching from the $17^{\text {th }}$ to $18^{\text {th }}$ centuries This then led to several movements aimed at banning racial discrimination against African-Americans and restoring their voting rights in the United States, which we know as the African-American Civil Rights Movement. This movement existed for 13 years, from 1955 to 1968.

One of the most important legislative achievements during the Civil Rights Movement phase is the issuance of the Civil Rights Act of 1964 which prohibits discrimination based on "race, color, religion, or national origin" in labor practices.

The rise of the civil rights struggle for African-Americans in the United States, however, gave rise to trauma that led to the hopes of the black nation. With the passing of the Civil Act, black citizens 
hope to regain their rights and freedoms that have been seized arbitrarily by white citizens, but on the other hand it also indirectly bequeaths traumas to their next generation, both for the skin nation black or white people.

This trauma and hope have deep meaning for black people, especially for those who survived these events and events (the survivors). These survivors do not keep memories of what they experienced for themselves but they tell again to their descendants and grandchildren so that these memories continue to survive among the black people from time to time. These memories also remain inherent in the generations after them, this generation is also called the post generation. This is in line with what is revealed by Eva Hoffman in the following quote:

The second generation is the generation of connections that receive, get the transfer of knowledge from events that are turned into history, or myths (Hirsch, 2012: 1)

From Hoffman's statement above we can see that the second generation or post generation are those who do not directly feel certain events that are revealed or told to them, but they keep the memories as what was experienced by the generation before them through the stories that reached them. This is what is known as Postmemory, a memory or memories passed down to the second generation and they live with those memories as if they have experienced them and become as part of themselves as the generation that sent them down. Marianne Hirsch revealed the term Postmemory in the following quote:

Postmemory describes the relationship of the next generation of personal trauma, collective trauma, and cultural trauma experienced by generations before them - for them to remember only based on the stories, archives, and behavior around them as they grow up. However, the experiences were transmitted affective and so profoundly that the experiences were their own memories (2012:5)

Survivors, or those who have experienced traumatic experiences, recount this to the generations after them and subsequent generations so that these traumatic cases endure from time to time and from generation to generation. Post generation lives with their post memory inherited from the first generation or survivors.

Traumatic matters are not infrequently contained in literary works, and one of the literary works in the form of novels containing traumatic experiences is a novel written by Sue Monk Kidd, The Secret Life of Bees. The Secret Life of Bees tells of Lily as the main character, a teenager on a peach farm in South Carolina whose mother died when she was young and her father was rude. In practice, Lily was raised by a black housekeeper, Rosaleen. When Rosaleen fought with several white men when she went to town to register to vote, Lily and Rosaleen decided to go together. They end up in a unique community which is the perfect place for Lily to find her mother and learn to love herself. Race issues emerge through this novel. Lily's relationship with black women and men and the city's willingness to ignore them is not entirely realistic; However, The Secret Life of Bees did a good job of addressing the tensions and inequalities that existed in the South in the 1960s. This paper tries to analyze how racism is transmitted by author Sue Monk Kidd and the memory reconstruction that occurs in it by focusing on the concept of postmemory. The source of data for this study is the novel The Secret Life of Bees, written by Sue Monk Kidd. As such, the analytical units of this study the words, phrases, clauses, and sentences from monologues and dialogues in the novel The Secret Life of Bees that are related to the postmemory concept.

\section{Literature Review}

\subsection{Memory Transmission}

In the postmemory case, the main lies in the transmission structure of the generation. This was revealed by Marianne Hirsch in her book The Generation of Postmemory: 
I argue that postmemory is not about the position of identity but a generation structure of transmission inherent in various forms (Hirsch, 2012: 35)

So it can be said that the most important thing in postmemory is the transmission of memory itself from the generation that experienced the event and passed on to the next generation, namely post generation. Post generation then lives with these memories which affect every aspect of their lives.

Hirsch divides memory transmission into two categories, namely familial transmission, and affiliative transmission. Familial transmission is a memory transmission that occurs at the family level that has a blood relationship between them. Hirsch stated:

'... the act of transferring memory appears more in the living room through the story being told, which indirectly indicates the existence of traumatic things' (Hirsch, 1992: 34)

Meanwhile, the affiliative transmission is a transmission that uses media other than family and the process of transferring the memory. This is expressed by Hirsch in the following quote:

Affiliative Memory is then nothing more than a loose extension of the family structure caused by war and torture. This is the result of a direct relationship combined with a set of available mediation structures, which can be adjusted and sufficient to show a wider transmission network. (Hirsch, 1992: 36)

Affiliative Memory is a form that complements familial memory on a broader and 'loose' level. This is due to the wider memory transmission at the affiliative level where the process of transmission is not only through memories stories as in familial memory but also includes other media such as monuments, photos, textbooks/stories, museums and others that tend to carry or are identical with certain memories.

\subsection{Memory Reconstruction}

Reconstruction of memory illustrates how the process of the second generation receives memories from survivors to themselves by knowing several things related to the background of events to find a relationship between events that happened in the past and their present. Hirsch stated:

This is a 'tale of survivors' ... a testimony ... mediated by the children of survivors through different representations and aesthetic choices. (2012: 26)

Hirsch's statement above illustrates how post generation receives memory transmissions from survivors and tries to repress these memories. This causes the memories passed down by the survivors to be reconstructed depending on the post generation's acceptance and representation. This shows that memories can change and are reconstructed from their original form, they are liquid so they tend to change depending on post generation reception.

\section{Discussion}

Memory is something that will never die as long as it continues to be told and passed down to subsequent generations. This narrative of memory to the next generation is called transmission, and transmission itself is an important element in postmemory studies. Hirsch argues that one can remember the memories of others: especially when it is a memory of a traumatic event in life, it will be remembered not only by those who experience it but also those who hear and know the event. They also remember it as if it were their own memories. The second generation who inherits these memories is referred to in Hirsch as 'The Hinge Generation'. 


\subsection{Memory Transmission}

The process of memory transmission occurs in the novel The Secret Life of Bees, this transmission appears in two forms, namely familial transmission, and affiliative transmission. Familial transmission is depicted when August the eldest brother in the Boatwright family tells the tragic story experienced by black people in America when they were worshiping in front of a black statue of Mary. The following excerpt from the story:

"Well," she said, "back in the time of slaves, when the
people were beaten down and kept like property, they
prayed every day and every night for deliverance."
August said, "Now, the oldest of the slaves was a woman
named Pearl. She walked with a stick, and when she
spoke, everyone listened. She got to her feet and said,
"This here is the mother of Jesus."

In the above quote, August tells the memories of their past situation to the family, church members, and also to Lily, a white girl who later was also touched by the story. This is a process of memory transmission carried out by August using stories about memories experienced by the black people, even though the story in this novel has gained a touch of fiction so that some additional stories are merely authored by mere authors. The story above also shows how the black people living in America are still experiencing the trauma of slavery and from the forms of racism, they have had in the past, even though those who lived at that time were no longer people who experienced slavery directly but they can clearly remember the story as tragic as their own memory. This is because memories of the story of slavery have always been passed down from generation to generation among the black nation.

This trauma and memory are not only experienced or transmitted among black people but also white people. They (white people) from the beginning until now as a result of racism have always felt superior to the black nation, especially in the past they had become the white nation whose fate depends on the employer to make the white nation increasingly look down on the black nation.

These memories also continue to be passed down from generation to generation so that even the white grandchildren who lived after the slavery of the black people were born and lived with these memories. They also became people who hated and despised black people. This is seen in the novel The Secret Life of Bees, which is when Rosaleen, a maid in the Lili family, takes Lily to town and they meet a group of white men who immediately confront them because they see a white-skinned Lily who is so familiar with Rosaleen who is black. They were stopped and Rosaleen was treated very badly. He was beaten for spilling into white shoes and forced to apologize. Lily, who was trying to save Rosaleen, was confronted by another white man and Rosaleen was taken to prison because of the case.

"Well, look what we got coming here," he called out. "Where're you going, nigger?"

"Did you ever see one that black?" said the dealer.

... When they looked up, I watched their faces go from surprise to anger, then outright fury. They lunged at her, and everything started to spin. There was Rosaleen, 
grabbed and thrashing side to side, swinging the men like pocketbooks on her arms, and the men yelling for her to apologize and clean their shoes.

"Clean it off!" That's all I could hear, over and over. "Call the police," yelled the dealer to a man inside. By then Rosaleen lay sprawled on the ground, pinned, twisting her fingers around clumps of grass. Blood ran from a cut beneath her eye. It curved under her chin the way tears do.

The quote above shows how white people acted arbitrarily to Rosaleen simply because he was a 'black'. They did not like seeing Lily walking side by side with Rosaleen because they thought it was inappropriate. White people are considered far better than black citizens.

From the paragraphs above it appears that familial and affilitive transmission is possible because of the repetition of memories received by the post generation. These repetitions become a form of confirmation about how traumatized the conditions experienced by their survivors.

\subsection{Memory Reconstruction}

The second generation tends to imagine when trying to recall memories or memories handed down to them. But when recalling memories that were told to them, those memories tend to change or are not exactly the same as the stories they get. This is caused by several factors, including because memory is fluid and tends to change every time someone tries to return to a particular memory. Besides, feelings and traumatic levels will also be different compared to survivors who experience the condition firsthand. When August recalled memories from the past when he was still working as a maid in Deborah's family home, Lily's mother. This memory construction was experienced by August when retelling her story to Lily while still working as a maid at Lily's mother's house. He cannot remember clearly what happened in the past,

August stared over my shoulder and smiled. "One time she ran away from home. I can't even remember what she was upset about. We looked for her long past dark. Found her curled up in a drainage ditch, sound asleep."

August can remember some details of events but some events are also forgotten. The same thing happened to Lily every time she tried to recall the events that had befallen her and her mother as a child. One memory that is very traumatic when he accidentally shot his mother when he was 4 years old. This shows the reconstruction of August's memory pad. Besides that, August has now lived in a time when their rights as blacks have been fought. This affected how August saw the white people and interacted with them.

\section{Conclusion}

Memory transmission both familial transmission and affiliative transmission is a form of repetition that is told through stories and other media related to certain events to the second generation or post generation. Even this second generation will feel that this is a memory before they at the same time also feel like their own memories and this is what is called post memory. Postmemory illustrates the relationship that generations after those who witnessed collective trauma events and endured their 
experiences that came before, experience that they "remember" only through the stories, images, and behaviors in which they grow. But these experiences are transmitted to them in-depth and affective which seems to be a reminder of their own rights.

This process of transmitting memory both affirmatively and familially occurs in the novel The Secret Life of Bees where the story of black people who have experienced slavery passed down from generation to generation through stories and what happens in their daily environment so that it continues to imprint on generations afterward and continue to influence them in their lives.

The memory transmitted to them also undergoes reconstruction because memory is fluid and tends to change depending on the conditions experienced by a person. In the novel The Secret Life of Bees, August undergoes a memory reconstruction where he cannot clearly remember some memories transmitted to him from generation to generation.

\section{Acknowledgements}

This paper is supported by Lembaga Pengelola Dana Pendidikan (LPDP) of the Republic Indonesia. The author is also gratefully acknowledge the helpful comments and suggestions from the reviewers, for the improvement of the presentation.

\section{References}

[1] Faruk. 2012. Literary Research Methods. Yogyakarta: Pustaka Belajar.

[2] Fernanda, Andri. 2017. Transmission of Memory and Trauma in Our Motherland by Dmitri: Postmemory Study. Thesis. Universitas Gadjah Mada. Yogyakarta

[3] Hirsch, Marianne. 2012. Family Frames: Photography, Narrative, and Postmemory. Cambridge, Massachusetts: Harvard University Press

[4] Hirsch, Marianne. 2012. The generation of Postmemory- Briting and Visual Culture after the Holocaust. New York: Columbia University Press

[5] Norva, Jalu Illa Putra. 2018. Bima and Ekalaya Construction in PULANG's Novel by Leila S. Chudori Postmemory Study. Thesis. Universitas Gadjah Mada. Yogyakarta

[6] Seprarisa, Amelia. 2016. The Bluest Eye: A Post Memory Study. Thesis. Universitas Gadjah Mada. Yogyakarta

[7] Vernalita, Riya Herwanti. 2015. A Study of Symbols in Sue Monk Kidd's The Secret Life of Bees. Skripsi. Universitas Sanata Darma 